\title{
Hyperosmolar Hyperglycemic State (HHS)
}

\author{
Rahayu Oktaliani ${ }^{1}$ Aywar Zamri ${ }^{2}$ \\ ${ }^{1}$ Dokter Muda Penyakit Dalam RSUD Raden Mattaher \\ ${ }^{2}$ Staf Dosen FKIK UNJA/Dokter Penyakit Dalam Konsultan Endokrin Metabolik Diabetes \\ Email: rahayuoktaliani@gmail.com
}

\begin{abstract}
ABSTRACK
Introduction: The Hyperosmolar Hyperglycemic State (HHS) is rare case and the most serious acute hyperglycemic emergency in patients with type 2 diabetes, are characterized by severe hyperglycemia, hyperosmolality, and dehydration in the absence of ketoacidosis. Immediately treatment is necessary to reinstate hemodynamic stability, as mortality rates for HHS are exceptionally high and can have multiple complications.

Case Presentation: In this case report, a 63-year-old man with a chiefly complaint from the body became weaker. Patients present with compos mentis, blood pressure $100 / 70 \mathrm{mmHg}$, regular pulse rate 110 times per minute with sufficient content and respiration 20 times per minute, and temperature $37,9^{\circ} \mathrm{C}$. Physical examination shows signs of dehydration. Investigation found white blood cell $12.58010^{3} / \mathrm{mm}^{3}$, plasma glucose $741 \mathrm{mg} / \mathrm{dL}$, and a negative urine ketone.

Conclusion: Case has been reported, a 63-year-old man with a diagnosis of HHS, the trigger factor for HHS in these patient are the discovery of infections as bronchopneumonia, elderly, and irregular diabetes treatment. The importance of treatment in this case is because the patient is elderly, treatment must be right because where too rapid rehydration may precipitate heart failure but insufficient may fail to reverse acute kidney injury.
\end{abstract}

Keywords: Diabetes Mellitus, Hyperosmolar Hyperglycemic State, Hyperglycemia

\section{ABSTRAK}

Latar Belakang : Hyperosmolar Hyperglycemic State (HHS) merupakan kasus yang jarang dan komplikasi emergensi akut dari pasien diabetes melitus tipe 2, dengan karakteristik hiperglikemi, hiperosmolar dan dehidrasi atau tidak adanya ketoasidosis. Tatalaksana segera penting dilakukan untuk menstabilkan hemodinamik, mortalitas dari HHS tinggi dan dapat menyebabkan banyak komplikasi.

Presentasi Klinis : Pada laporan kasus ini, seorang laki-laki berusia 63 tahun dengan keluhan utama badan semakin lemas. Pasien datang dengan kesadaran kompos mentis, tekanan darah 100/70 $\mathrm{mmHg}$, nadi teraba 110 kali per menit kuat regular dengan isi cukup dan respirasi 20 kali per menit, dan suhu $37,9^{\circ} \mathrm{C}$. Pemeriksaan fisik didapatkan tanda-tanda dehidrasi. Pemeriksaan penunjang dijumpai sel darah putih 12.580, glukosa plasma $741 \mathrm{mg} / \mathrm{dL}$, dan keton urine negatif.

Kesimpulan : Telah dilaporkan kasus, laki-laki usia 63 tahun dengan diagnosa HHS, faktor pencetus terjadinya HHS pada pasien ini yaitu ditemukannya infeksi berupa bronkopneumonia, usia lanjut, pengobatan diabetes yang tidak teratur. Pentingnya perawatan dalam kasus ini adalah karena pasien berusia lanjut, pengobatan harus benar karena ketika rehidrasi yang terlalu cepat dapat memicu gagal jantung tetapi tidak cukup dapat gagal untuk membalikkan cedera ginjal akut.

Kata Kunci : Diabetes Melitus, Hyperglycemic Hyperosmolar State, Hiperglikemi 


\section{PENDAHULUAN}

Kejadian Diabetes Melitus terus meningkat, data dari International Diabetes Federation menunjukkan pada tahun 2015, 415 juta orang dewasa menderita DM di dunia dan jumlahnya diperkirakan akan meningkat menjadi 642 juta pada 2040, ${ }^{1}$ Pada tahun 2015 Indonesia menempati peringkat tertinggi ke tujuh di dunia. Diabetes dengan komplikasi merupakan penyebab kematian tertinggi ketiga di Indonesia. ${ }^{2}$ Komplikasi akut dari diabetes melitus adalah Ketoasidosis Diabetik (KAD) dan Hyperosmolar Hyperglycaemic State (HHS). ${ }^{3}$

HHS adalah suatu keadaan darurat diabetes yang mengancam nyawa, ${ }^{4}$ sering terjadi pada penderita usia lanjut. ${ }^{5}$ Angka kematian keseluruhan diperkirakan $20 \%$, yaitu sekitar 10 kali lebih besar dari Ketosidosis Diabetik (KAD). Prognosis ditentukan oleh tingkat beratnya dehidrasi, adanya komorbiditas, dan usia lanjut. ${ }^{4}$
HHS merupakan gangguan metabolik akut yang ditandai dengan hiperglikemia, hiperosmolaritas, dan dehidrasi tanpa adanya ketoasidos. Faktor pencetus krisis hiperglikemia ini antara lain infeksi (pneumonia, infeksi saluran kencing, sepsis), penyakit vaskular akut, trauma, luka bakar, hematom subdural, kelainan gastrointestinal, obat-obatan. ${ }^{6}$

HHS dimulai dengan adanya diuresis glukosuria, glukosuria menyebabkan kegagalan pada kemampuan ginjal dalam mengkonsentrasikan urin, hilangnya air yang lebih banyak dibanding natrium menyebabkan kegagalan hiperosmolar. ${ }^{7}$

Tujuan dari terapi HHS adalah untuk rehidrasi intravena secara agresif, penurunan secara bertahap kadar glukosa serum, penurunan osmolalitas plasma, koreksi ketidakseimbangan elektrolit, mengatasi faktor pencetus dan melakukan monitoring serta intervensi terhadap gangguan fungsi kardiovaskular, paru, ginjal dan susunan saraf pusat. $^{8}$

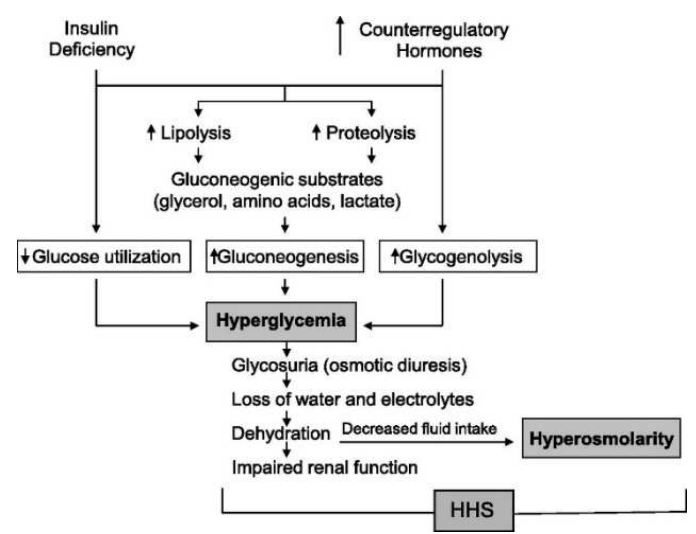

Gambar 1 Patofisiologi HHS

\section{LAPORAN KASUS}

Seorang laki-laki berusia 63 tahun datang ke RSUD Raden Mattaher Provinsi
Jambi dengan keluhan badan yang terasa lemas sejak \pm 1 bulan sebelum masuk rumah sakit, lemas dirasakan disertai lesu 
dan cepat lelah, lemas terus-menerus sepanjang hari, tidak membaik dengan istirahat, terdapat adanya penurunan berat badan kurang lebih sejak 2 tahun terakhir, dari awalnya $70 \mathrm{~kg}$ menjadi $57 \mathrm{~kg}$, penurunan berat badan tidak diketahui penyebabnya, walaupun pasien sering merasa lapar dan banyak makan. Selain itu pasien juga mengeluh sering terbangun dimalam hari untuk buang air kecil, dengan frekuensi $>7$ kali, dengan volume $\pm 250 \mathrm{cc}$.

Pasien makan teratur $>3 x$ sehari dan sering makan-makanan manis. Pasien menderita kencing manis sejak 8 tahun yang lalu, sehari-hari mengkonsumsi obat metformin $3 \times 500 \mathrm{mg}$ dan glibenclamid $1 \times 5 \mathrm{mg}$, minum obat tidak rutin, minum obat jika pasien merasa keluhan seperti lemas muncul, kemudian jika membaik pasien tidak minum obat kembali, pasien tidak mengetahui risiko jika minum obat tidak teratur. \pm 1 minggu sebelum masuk rumah sakit, pasien mengeluh pandangan kabur pada kedua mata, tidak disertai dengan pandangan ganda, nyeri kepala (-), batuk (+) awalnya batuk ringan dan tidak berdahak, tetapi semakin lama batuk semakin memberat dan berdahak. Pasien juga merasa kebas dan kesemutan di kaki, kebas dirasakan dari ujung kaki hingga pangkal paha, tidak membaik dengan istirahat. \pm 1 hari SMRS, pasien merasakan badan yang semakin memberat lemas, pasien tidak dapat melakukan aktivitas seperti biasanya dan hanya terbaring di tempat tidur. Demam $(+)$ penurunan kesadaran (-), mengantuk (-), mual (-) muntah (-) sesak nafas (-).
Keadaan umum pasien tampak sakit sedang, dengan kesadaran kompos mentis, tekanan darah : 100/70 mmHg, respirasi 20 kali/menit, nadi 110 kali/menit, dan suhu $37,9^{\circ}$ C. Pada pemeriksaan fisik ditemukan mata konjungtiva anemis, terdapat tandatanda dehidrasi sedang pada pasien ini yaitu mata cekung, bibir kering dan merasa haus. Pada pemeriksaan laboratorium, gula darah sewaktu pasien saat masuk IGD sangat tinggi yaitu $741 \mathrm{mg} / \mathrm{dl}$ dan memerlukan penurunan gula darah untuk mencegah terjadinya komplikasi lebih Ianjut.

Pada pasien ini keton urin (-), pemeriksaan osmolalitas serum, keton darah dan analisa gas darah tidak dilakukan. Pemeriksaan darah rutin didapatkan leukosit meningkat (leukositosis), sel darah merah dan hemoglobin menurun (anemia), dan terjadi peningkatan trombosit (trombositosis). Pemeriksaan laboratorium urin rutin, $\mathrm{pH}$ 6, protein dan glukosa urin (+3), keton (-). Pemeriksaan elektrolit didapatkan natrium yang rendah (hiponatremi) $122 \mathrm{mmol} / \mathrm{L}$.

\section{PEMBAHASAN}

Kasus ini merupakan kejadian yang jarang ditemukan, jika ada risiko kematian sangat tinggi, sehingga perlunya penaganan lebih baik mengenai kasus ini. Seorang pasien diabetes melitus berusia 63 tahun dengan pengobatan tidak teratur, pasien hanya meminum obat jika keluhan muncul dan tidak mengetahui risiko yang akan terjadi jika tidak minum obat teratur, selain itu pasien juga mengeluhkan batuk yang tidak kunjung sembuh dengan sputum 
mukoid kemudian diikuti dengan demam menggigil, sakit tenggorok, nyeri otot dan sendi. Dari pemeriksaan fisik didapatkan ronki basah halus. Didapatkan peningkatan leukosit yaitu 12.580, dilakukan pemeriksaan rontgen thorax dengan gambaran infiltrat perihiler dan basal paru, kemudian ditegakkan diagnosa bronkopneumonia.

Hal ini sesuai dengan teori yaitu HHS sering terjadi pada pasien usia lanjut dengan diabetes tipe 2. Faktor predisposisi terjadinya HSS paling umum adalah infeksi pada $40-60 \%$ pasien, dan infeksi yang paling sering adalah bronkopneumonia, selain itu pada pasien ini memiliki riwayat minum obat yang tidak teratur. Faktor-faktor inilah yang dapat mencetuskan terjadinya HHS. $^{9}$

Diagnosis HHS pada pasien ini ditegakkan dari hasil anamnesis berupa poliuria, polidipsi dan penurunan berat badan yang berlangsung. Pemeriksaan fisik didapatkan konjungtiva anemis dan tandatanda dehidrasi. Pemeriksaan penunjang dijumpai glukosa plasma $741 \mathrm{mg} / \mathrm{dL}$, dan keton urine negatif. Sangat disayangkan pada pasien ini tidak dilakukan pemeriksaan analisa gas darah untuk dapat membedakan HHS dengan KAD. Walaupun dari anamnesis dan pemeriksaan fisik dapat menegakan HHS, setidaknya pemeriksaan analisa gas darah harus dilakukan untuk penanganan yang adekuat.

Tujuan terapi cairan pada HHS adalah untuk memperluas volume intravaskular dan ekstravaskular, tanpa menyebabkan edema serebral karena pengurangan osmolalitas plasma yang terlalu cepat.
Pemberian $\mathrm{NaCl}$ 0,9\% 1 liter pada waktu 060 menit dan 1 liter dalam 60 menit- 6 jam. Pengobatan insulin sebelum penggantian cairan yang adekuat dapat menyebabkan kolapsnya kardiovaskular saat air keluar dari ruang intravaskular yang mengakibatkan penurunan volume intravaskular. Pemberian insulin 0-60 menit berupa drip insulin $50 \mathrm{IU}+50 \mathrm{cc} \mathrm{NaCl}$ 0,9\%, kemudian cek gula darah. Insulin dosis rendah 0,05 unit/kg/jam hanya boleh dimulai setelah gula darah tidak lagi turun dengan cairan IV saja atau segera jika ada ketonaemia yang signifikan (ketonemia darah kapiler> $1 \mathrm{mmol} / \mathrm{L})$. Pemantauan gula darah dilakukan per jam. ${ }^{10}$

Terapi pada HHS yaitu untuk penggantian volume sirkulasi dan perfusi jaringan, penurunan secara bertahap kadar glukosa serum dan osmolalitas plasma, koreksi ketidakseimbangan elektrolit, mengatasi faktor pencetus, melakukan monitoring dan intervensi terhadap gangguan fungsi kardiovaskular, paru, ginjal dan susunan saraf pusat.

Pada pasien ini telah dilakukan penanganan di IGD yaitu IVFD Nacl 0,9\% loading 2 kolf, injeksi insulin 10 iu subkutan, dan drip aspart 50iu+50cc Nacl 0,9\% menggunakan syringe pump mulai 3 iu/jam, cek Gula Darah Sewaktu (GDS) jika GDS 100-150mg/dl: 1 iu/jam, 151-250mg/dl: 2 iu/jam, 251-300mg/dl: 3 iu/jam, 300350mg/dl: $4 \mathrm{iu} / \mathrm{jam}$ dan >350mg/dl: $5 \mathrm{iu} / \mathrm{jam}$.

Terlihat perbedaan pada teori dan penanganan kasus ini, sesuai teori rehidrasi intravena dilakukan 0-60 menit 1 liter dan 60 menit sampai 6 jam 1 liter Nacl $0,9 \%$, hal ini bertujuan agar tidak terjadi 
overload cairan. Pemberian insulin pada tahap awal juga dengan menggunakan dosis 0,05 unit/kg/jam. Berat badan pasien $57 \mathrm{~kg}$ sehingga insulin dibutuhkan 3 unit/jam. Penurunan gula darah secara cepat dengan insulin tidak direkomendasikan karena dapat menyebabkan kolapsnya pembuluh darah. Faktor pencetus HHS pada pasien ini adalah bronkopneumoni sehingga perlu dilakukan kultur dahak untuk menentukan antibiotik yang dipilih. Namun pada pasien ini tidak dilakukan, pengobatan awal dapat menggunakan antibiotik spektrum luas seperti ceftriaxone.

Pada pasien ini diduga telah terjadi neuropati diabetik dan retinopati diabetik, hal ini didapatkan dari keluhan pasien yang merasakan kebas dan kesemutan di kaki, kebas dirasakan dari ujung kaki hingga pangkal paha, tidak membaik dengan istirahat. Perlu dilakukan pengkajian terhadap refleks motorik, tes rasa getar dan rasa tekan, mikrofilamen dan elektromiografi, jika terdapat kelainan dapat diberikan gabapentin. ${ }^{11}$ Pasien mengeluh pandangan kabur pada kedua mata, tidak disertai dengan pandangan ganda, sehingga perlu di konsulkan ke dokter mata untuk melakukan pemeriksaan funduskopi.

\section{KESIMPULAN}

Telah dilaporkan kasus, laki-laki usia 63 tahun dengan diagnosa HHS, faktor pencetus terjadinya HHS pada pasien ini yaitu ditemukannya infeksi berupa bronkopneumonia, usia lanjut, pengobatan diabetes yang tidak teratur. Pentingnya perawatan dalam kasus ini adalah karena pasien berusia lanjut, pengobatan harus benar karena ketika rehidrasi yang terlalu cepat dapat memicu gagal jantung tetapi tidak cukup dapat gagal untuk membalikkan cedera ginjal akut.

\section{SARAN}

Pentingnya edukasi kepada pasien mengenai pemantauan kosentrasi gula darah mandiri, minum obat teratur dan edukasi dengan tujuan promosi hidup sehat perlu dilakukan sebagai bagian yang sangat penting dari pengelolaan DM secara holistik. Pada kasus ini diharapkan pemeriksaan sebaiknya dilakukan secara komprehensif, walaupun diagnosis HHS dapat ditegakkan dari klinis, namun konfirmasi dengan pemeriksaan laboratorium harus dilakukan, sehingga sangat penting sekali dilakukan pemeriksaan analisa gas darah pada kasus ini untuk menghidari salah diagnosa. Selain itu pemeriksaan fisik lengkap mulai dari kepala sampai kaki yang berkaitan dengan komplikasi dari DM perlu dilakukan sebagai penangan DM yang komprehensif. 


\section{DAFTAR PUSTAKA}

1. Wenjun, Fan. Epidemiology in diabetes mellitus and cardiovascular disease. Cardiovascular Endocrinology \& Metabolism; 2017.

2. World Health Organization. Diabetes angka dan fakta; 2016.

3. Sudoyo AW, Setiyohadi B, Alwi I, Simadibrata M, Setiati S. Buku ajar ilmu penyakit dalam jilid II. Edisi ke-6. Jakarta: Interna Publishing; 2014.

4. Joint British Diabetes Societies Inpatient Care Group. The management of the hyperosmolar hyperglycaemic state (HHS) in adults with diabetes. NHS; 2012.

5. Harrison. Principles of internal medicine. Volume 1. 20th edition. Mcgraw-hill education; 2018.

6. Semarawima, G. Status hiperosmolar hiperglikemik: Rumah Sakit Umum Pusat Sanglah Denpasar Bali; 2017.

7. Setyoahadi, B. dkk. EIMED PAPDI Kegawatdaruratan penyakit dalam (emergency in internal medicine). Volume I. Jakarta : Internal Publishing; 2012.

8. Francisco J. Guillermo E. Umpierrez. Hyperosmolar Hyperglycemic State: A Historic Review of the Clinical Presentation, Diagnosis, and Treatment: American Diabetes Association; 2014.

9. American Diabetes Association. Standards of medical care in diabetes; 2018.

10. Liverpool Hospital. Guideline management of hyperosmolar hyperglycemic state. NSW Government; 2016.

11. PERKENI. Pengelolaan dan pencegahan diabetes melitus tipe 2 di Indonesia. Jakarta: 2015. 